\title{
Is a faster pace of letter instruction associated with other teaching practices?
}

\author{
Kristin Sunde* and Kjersti Lundetræ \\ University of Stavanger
}

\begin{abstract}
The past few years have seen a shift towards a faster pace of letter instruction in Norwegian firstgrade classrooms. Introducing the letters faster has the potential to alter teaching practices more generally, not only by freeing up time for more individually adapted literacy instruction but also by making it possible for students to start reading and writing texts earlier. The aim of the present study is to investigate whether the pace of letter instruction is associated with the amount of time devoted to various other relevant teaching practices. Information about the pace of letter instruction and about other teaching practices was provided, through questionnaires completed in December and June, by 51 Norwegian first-grade teachers who finished letter instruction at various times between September and June. The results indicate that introducing the letters faster really does affect other teaching practices, mainly in the second semester, in that more time is devoted to students' writing, greater use is made of levelled books and less time is spent on worksheets and on handwriting practice. However, there would seem to be room for teachers to further exploit the opportunities that arise when the letters are introduced faster.
\end{abstract}

Keywords: Letter learning; pace of letter instruction; teaching practices; first grade

Responsible editor: Per Henning Uppstad

Received: March, 2019; Accepted: August, 2019; Published: November, 2019

\section{Introduction}

For decades, the literacy instruction offered to school starters has been characterised by detailed letter instruction over a lengthy period of time, typically involving the presentation of one new letter each week (Morrow, Tracey, \& Del Nero, 2011; Rasmussen, 2013; Treiman, Tincoff, Rodriguez, Mouzaki, \& Francis, 1998). This aspect of first-grade practice can be considered a historically stable cornerstone of literacy instruction, across countries. However, recent years have seen rapid change in Norwegian first-grade classrooms, with more and more teachers introducing the letters at a faster pace. While only $18 \%$ of teachers reported that they introduced

\footnotetext{
^Correspondence: Kristin Sunde, University of Stavanger, email: kristin.sunde@uis.no 
two or more letters a week in 2013 (Rasmussen, 2013), approximately $60 \%$ did in 2016 (Norwegian Reading Centre, 2017). Against this background, it is relevant to ask whether such a major change in a key element of first-grade literacy instruction has the potential to significantly alter instructional practices at a more general level. More specifically, we investigate whether the change to an instructional cornerstone represented by a faster pace of letter instruction is associated with the frequencies of other teaching practices in the first grade.

\section{Possible effects of a faster pace of letter instruction}

One of the main advantages of introducing the letters faster in the first grade is obviously that this will give students access sooner to the tools they need for reading and writing, and this in turn will give the teacher better opportunities to provide more adapted instruction to all students - from those who struggle with mastering all letter-sound correspondences, to those who quickly need more advanced tasks to further develop their literacy skills (see e.g. Lundetræ \& Uppstad, 2016; Lundetræ \& Walgermo, 2014). This way of thinking reflects a hermeneutic approach to reading instruction, as proposed by Tønnessen and Uppstad (2015, pp. 90-91). Hermeneutics began life as a theory on the interpretation of texts, emphasising that neither the parts nor the whole can be fully understood without the other (Gadamer, 1960). Transferred to reading instruction, teachers should ensure, as early as possible, that students have many opportunities to encounter both parts (letters, and later on words) and wholes (words, and later on texts). Students' encounters with words will help develop their knowledge about how the letters are used in individual words. At the same time, using their knowledge of the individual letters to read and spell different words will develop their knowledge about those words.

Research into the pace of letter instruction is scarce. The few studies carried out have found that introducing the letters faster is positively associated with children's letter knowledge, word-reading skills and spelling skills at the end of the first grade (Jones \& Reutzel, 2012; Sunde, Furnes, \& Lundetræ, 2019). As far as we know, however, no previous studies have investigated the domino effect that a faster pace of letter instruction may have on other teaching practices in first-grade classrooms.

\section{Practices used in first-grade literacy instruction}

Norwegian school starters vary greatly in their knowledge of the letters and their other literacy skills (Djuve, 2017; Sigmundsson, Eriksen, Ofteland, \& Haga, 2017). As Norwegian kindergartens offer no formal literacy instruction (Norwegian Directorate for Education and Training, 2017a), there is typically an emphasis on explicit teaching of letter-sound correspondences, word reading and spelling during the first year of school.

Explicit instruction about grapheme-phoneme correspondences, or "phonics", has been found to strengthen children's letter knowledge and their ability to read 


\section{K. Sunde and K. Lundetre}

words (National Institute of Child Health and Human Development, 2000; Torgerson, Brooks, \& Hall, 2006). Existing research also recognises that children should encounter multiple repetitions of grapheme-phoneme associations after the first introduction of the letters (Jones, Clark, \& Reutzel, 2013; Justice, Pence, Bowles, \& Wiggins, 2006; Treiman et al., 1998). However, many students have mastered all such associations even after the first round of instruction while others need several repetitions of most of the letters, or of those that are easily confused, such as $b$ and $d$. If the letters are introduced more rapidly than at the traditional one-letter-a-week pace, teachers will have greater opportunities to ensure that each student is exposed to the amount of repetition that he or she needs (Jones et al., 2013).

Here it should be noted that the letters are of limited usefulness, and hence interest, in and of themselves. After all, letters do not create meaning unless they are used for reading and writing. Using the letters for reading and writing will in fact provide students with multiple repetitions of grapheme-phoneme correspondences. For this reason, it has been recommended that students should use the letters in meaningful reading and writing activities as soon as they have been introduced to them (Ehri, 2004; Jones et al., 2013; Tønnessen \& Uppstad, 2015).

Against this background, teachers should give students opportunities to practise their reading and writing in meaningful and authentic settings at school (Adams, 1990; Allington, 2013; Castles, Rastle, \& Nation, 2018; Gambrell, 2011; Gerde, Bingham, \& Wasik, 2012). In this study, we use the term "meaningful" about reading of authentic texts such as children's books, magazines and levelled books and tasks that allow students to communicate their ideas, opinions and experiences through writing (Gerde et al., 2012). Extensive use of the opposite type of tasks, such as completing worksheets, practising handwriting by forming individual letters and practising the reading of parts of words or single words (e.g. reading sheets) represents a more fragmented approach to literacy instruction. If teachers rely too much on such less meaningful tasks, students may form the impression that reading and writing is something you do to practise specific skills rather than to search for meaning or to communicate.

\section{Reading in first-grade classrooms}

By the end of the first grade, most students no longer rely entirely on letter-sound correspondences when reading but also use orthographic and more advanced word-reading skills to a lesser or greater extent. For this transition to take place, students' own reading is crucial. This is because frequent encounters with words through extensive reading is the most influential factor when it comes to strengthening the ability to recognise words (Castles et al., 2018; Foorman et al., 2006). On this point, there will obviously be differences between languages depending on their degree of transparency. In a semi-transparent orthography like that of Norwegian, students simply cannot master complex words with inconsistent spelling unless they go beyond letter-sound correspondences (Seymour, Aro, \& Erskine, 2003). Explicit instruction can be used to some extent to teach students such inconsistencies between 
spoken and written language, but students still have to read those words in context in order to learn how to pronounce and spell them (Castles et al., 2018; Ehri, 2005). In fact, the total time devoted to reading has been found to be crucial for subsequent reading development (Castles et al., 2018; Willingham, 2017), but the time spent reading by students at school varies greatly between classrooms (Brenner, Hiebert, \& Tompkins, 2009; Topping, Samuels, \& Paul, 2007). Both quantity and quality are important: students must be provided with texts at an appropriate level of difficulty (Gambrell, 2011; Stutz, Schaffner, \& Schiefele, 2016; Turner \& Paris, 1995; Wray, Medwell, Fox, \& Poulson, 2000).

\section{Writing in first-grade classrooms}

Early on, children often find it easier to write words than to read them (Adams, 1990). In fact, about half of Norwegian school starters already know how to spell simple words (two- to five-letter ones) (Djuve, 2017). Children's initial attempts at using letters to convert spoken words into text - "invented" spelling or writing (Puranik \& Lonigan, 2011; Read, 1971) - also help them understand the alphabetic principle by promoting their ability to analyse words into their constituent phonemes and to link phonemes with the corresponding graphemes (Frith, 1985).

There is of course also a motor element to writing. One basic prerequisite for children to be able to write words and texts by hand is the ability to write individual letters efficiently using a pen or pencil. Hence this is an important component of first-grade letter instruction, but the related lessons should be brief and explicit (Jones et al., 2013), and the practice of handwriting skills beyond the initial level should take place mainly in the context of meaningful writing activities (Graham et al., 2012).

Time set aside by teachers for students' writing is thus crucial for the practice of both handwriting and writing at a more abstract level. However, the effect on students' skills may largely depend on teachers' specific use of such time (Roth \& Guinee, 2011). The recommended time that students should spend writing each day ranges from 10 to 45 minutes (Graham et al., 2012; Morrow et al., 2011; Ray \& Cleaveland, 2004) - also depending on context and on the level of teacher support. As in the case of reading, there is considerable variation across classrooms in the time set aside for students' writing (Cutler \& Graham, 2008; Håland, Hoem, \& McTigue, 2019). This might in fact reflect an untapped potential for children's literacy learning.

In a previous study, Håland et al. (2019) ( $N=299$ Norwegian classrooms, of which 51 are included in the present study) found no association between the pace of letter instruction and the time provided for students to write in the first semester. However, as many as $19 \%$ of the teachers in their study reported that they provided no time at all for students' own writing in the first semester. Two main reasons were given: first, that the faster pace of letter instruction required a great deal of classroom time, and, second, that they preferred a fragmented and sequential 


\section{K. Sunde and K. Lundetre}

approach to teaching and learning, considering that students should first learn the letters properly and only then use them to write texts. These findings run contrary to researchers' recommendations for a faster pace of letter instruction, which are based on the assumption that introducing the letters faster will create better opportunities to engage students in meaningful reading and writing activities at an earlier stage (Jones et al., 2013; Lundetræ \& Uppstad, 2016; Lundetræ \& Walgermo, 2014; Tønnessen \& Uppstad, 2015).

\section{The present study}

The aim of the present study was to investigate whether a faster pace of letter instruction has the potential to alter literacy instruction at a more general level. As mentioned above, the practice of introducing the letters over a lengthy period of time has been a historically stable cornerstone of first-grade literacy instruction across countries, but in recent years there has been a rapid shift towards a faster pace of letter instruction as the prevailing approach in Norwegian first-grade classrooms. To investigate the potential domino effect of that faster pace of letter instruction on other teaching practices, we asked the following question:

Is the pace of letter instruction in Norwegian first-grade classrooms associated with the frequency of other teaching practices, such as time spent on students' own reading and writing, handwriting practice and worksheets, the use of different reading material and the extent to which the teachers adapt their instruction?

This question was underpinned by several assumptions. First, we hypothesised that spending less time on letter instruction for all students would provide teachers with better opportunities to adapt their instruction to individual students' skills and needs. Hence we expected to find higher frequencies of adapted letter instruction and other tasks as well as more extensive use of levelled books in classrooms where the letters were introduced more rapidly. Second, we hypothesised that a faster pace of letter instruction would enable students to use all letters for reading and writing at an earlier time. Hence we expected that teachers who finished letter instruction early would allocate more time for their students to read and write in meaningful settings and devote less time to tasks focusing on single letters and words, such as handwriting practice and tasks based on worksheets and reading sheets. Third, we hypothesised that the pace of letter instruction would be more strongly associated with the frequency of other teaching practices in the second semester than in the first. The reason for this expectation was twofold. To begin with, letter instruction continued throughout the first semester in most classrooms, meaning that it would presumably leave less time for other teaching practices. Further, in the course of the second semester, as more and more teachers finished their letter instruction, other options would become available to them in planning literacy instruction: they would have better opportunities to adapt their instruction to the students' individual needs and more time to devote to 
meaningful reading and writing activities that would better support the students' literacy learning.

\section{Method}

\section{Participants and procedures}

The present study is based on survey data from the 51 class teachers ( 50 females) randomised to the untreated control group in the large "Two Teachers" randomised controlled trial ( $N=300$ classrooms) (Solheim, Rege, \& McTigue, 2017). Seven teachers were 29 years old or younger, twelve were 30-39, sixteen were 40-49, thirteen were 50-59 and two were above 60 years old. Four teachers held a master's degree, forty-three held a three- or four-year teaching degree and the remaining three reported having a university degree of three years' duration or less. The teachers' work experience ranged from 1 to 36 years (mean: 12.56). Of the twenty-seven teachers who had finished letter instruction by December, sixteen reported that this was their first time introducing two or more letters a week. When the teachers were asked to reply to the following assertion: "In reading instruction; we teach students to take sounds together to form words", forty-eight teachers answered "totally agree" and three teachers answered "partly agree", indicating that a phonics based approach to reading instruction dominates. The classrooms participating in the study are widely spread across the southern part of Norway, representing twenty-six municipalities in eight counties, and they mirror overall Norwegian demographics in that $83.3 \%$ of the children attending the schools in question live in urban areas ( $82 \%$ do so in Norway overall) (Statistics Norway, 2018).

\section{The Norwegian context}

Norwegian children start school in August of the calendar year in which they turn six. Between the ages of three and five, $96.8 \%$ of children attend kindergarten (Statistics Norway, 2017), but starting school proper represents the onset of formal literacy instruction. Most children (96.5\%) are enrolled in public (i.e. non-private) schools, and only $0.5 \%$ attend special-education schools (Norwegian Directorate for Education and Training, 2018b). The Norwegian subject has the main responsibility for literacy instruction, and covers eight out of 25 school hours (á 45 minutes) a week in first grade (Norwegian Directorate for Education and Training, 2018a).

The current Norwegian national curriculum (Norwegian Directorate for Education and Training, 2017b) is organised on the basis of competence aims that students should meet after certain grade levels. For the questions under investigation in this study, the relevant competence aims are to be met after the second grade. Norwegian teachers have a great deal of professional autonomy: they are free to choose their teaching methods and approaches, as long as they direct their teaching towards the competence aims. 


\section{K. Sunde and K. Lundetre}

\section{Measures and analyses}

The measures were retrieved from the answers to a questionnaire survey administered to teachers within the "Two Teachers" project on two occasions during the academic year (in December and June). The survey contained, inter alia, questions about the teachers' teaching practices with regard to letter instruction, reading and writing and was sent to the Norwegian subject teacher. Most of the questions that are relevant to the present study were developed by experienced researchers and practitioners involved in the "Two Teachers" project, but the scale used to elicit information about adapted teaching practices was adapted from Wendt, Bos, Tarelli, Vaskova, and Walzebug (2016). On both occasions, the teachers were asked to report based on a typical week in the current semester.

The questionnaire, which was first piloted on a group of teachers not involved in the project, was web-based, with a personal link sent by e-mail to each respondent. For the teachers involved in the present study, the response rate was $100 \%$ at both time points, but one teacher failed to complete parts of the second questionnaire, meaning that several questions on the June questionnaire have one answer missing.

Based on our hypotheses as set out above, we chose a subset of the questionnaire items as described below. Descriptive statistics for those items are provided in Table 1.

Time for students' own reading was assessed using the item "How many minutes are set aside for the students' own reading each week?" It was specified that it referred to students' own reading of children's books/magazines, not teacher-led instruction and homework consisting of reading tasks. This variable is referred to as "time to read". The scale used is: $1=$ less than 15 minutes; 2 = about 15 minutes; $3=$ about 30 minutes; $4=$ about 45 minutes; $5=$ about 60 minutes; $6=$ about 75 minutes; $8=$ about 90 minutes; and $9=$ more than 90 minutes.

Time for students' own writing was assessed using the item "How much time is allocated to students' own writing each week?" It was specified in the question that it referred to time for students to engage in actual writing, not including time devoted to, for example, pre-writing activities, handwriting practice or worksheets. This variable is referred to as "time to write". The scale used is: $1=$ have not spent time on writing texts yet; $2=$ less than 15 minutes; $3=$ about 15 minutes; $4=$ about 30 minutes; 5 = about 45 minutes; $6=$ about 60 minutes; and $7=$ more than 60 minutes. The first value ( $1=$ have not spent time on writing texts yet) was used only in the December questionnaire, as some teachers tend to wait until all letters are introduced before they allocate time for students own writing.

Use of reading materials was assessed using two items: (a) "How often do you use levelled books/guided reading books?" (variable name: "levelled books") and (b) "How often do you use reading sheets?" (variable name: "reading sheets"). Reading sheets, which are used in many Norwegian first-grade classrooms, typically contain a set of letters, syllables, words and sentences for the students to read. They often include only those letters that have been introduced so far. The scale used for both 
variables is $1=$ every day/nearly every day; $2=$ once or twice a week; $3=$ once or twice a month; and $4=$ never or rarely.

Use of writing tasks was also assessed using two items: (a) "Are tasks targeting handwriting/letter forming used in the classroom?" (variable name: "handwriting") and (b) "Are cloze tasks in books/worksheets used in the classroom?" (variable name: "worksheets"). The same 1-4 scale as described in the previous paragraph was used.

Repetition of letters was assessed only in the June questionnaire, using three items: (a) "After the first introduction of the letters, we have gone through all the letters systematically one or several times in whole-class sessions" (variable name: "repeated letters systematically"); (b) "After the first introduction of the letters, we have repeated the letters regularly with all students in the class" (variable name: "repeated letters regularly"); and (c) "After the first introduction of the letters, we have repeated the letters with those students who did not know all the letters after the first round of instruction" (variable name: "repeated letters with individual students"). The same 1-4 scale was used.

Finally, the adaptation of tasks to students' skill level (variable name: "adapted instruction") was assessed only in the June questionnaire, using an adapted version of a scale designed by Wendt et al. (2016). A factor analysis was performed to elaborate this variable. Nine items were initially entered, but four of them were removed owing to a low loading on the one-factor solution ${ }^{1}$. The five items eventually included in the one-factor solution (Cronbach's $\alpha=.82$ ) are: "The students are given tasks of varying difficulty depending on their ability" (factor loading $=.807$ ); "Those students who struggle understanding something are given specific additional tasks" (factor loading = .602); "High-ability students are given additional or more demanding tasks" (factor loading = .756); "When students work individually, the tasks they are set are adapted to their ability level" (factor loading = .811); and "The students regularly work on tasks of varying difficulty, either in groups or on their own" (factor loading = .841) The Kaiser-Meyer-Olkin (KMO) value for sampling accuracy was .81 , which exceeds the recommended threshold value of .6 (Kaiser, 1970, 1974). Bartlett's test of sphericity (Bartlett, 1954) yielded a low significance level $(p<.001)$, supporting the factorability of the correlation matrix.

Table 1. Descriptive statistics for variables indicating frequencies of teaching activities.

\begin{tabular}{lcccc}
\hline & N & Min-max & Mean (SD) & Skewness/kurtosis \\
\hline December & & & & \\
Time to read & 51 & $1-5$ & $2.33(1.11)$ & $-0.49 /-0.36$ \\
Time to write & 51 & $1-7$ & $3.55(1.83)$ & $-0.40 /-0.75$
\end{tabular}

${ }^{1}$ The excluded variables were: "Teaching is oriented towards the mean ability level of the class"; "Low-ability students receive extra help during lessons"; "During group work the groups are divided according to ability, and the groups receive different tasks"; and "I use software to differentiate teaching". 


\begin{tabular}{lcccc}
\hline & N & Min-max & Mean (SD) & Skewness/kurtosis \\
\hline Levelled books & 51 & $1-4$ & $2.82(1.05)$ & $-0.38 /-1.07$ \\
Reading sheets & 51 & $1-4$ & $2.31(1.03)$ & $0.47 /-0.87$ \\
Worksheets & 51 & $1-4$ & $1.94(0.90)$ & $0.97 / 0.47$ \\
Letter forming & 51 & $1-4$ & $1.82(0.84)$ & $0.98 / 0.68$ \\
\hline fune & & & \\
Time to read & 50 & $1-8$ & $3.16(1.66)$ & $1.16 / 1.32$ \\
Time to write & 50 & $1-7$ & $4.28(1.49)$ & $-0.04 /-0.60$ \\
Levelled books & 50 & $1-4$ & $2.34(1.02)$ & $0.22 /-1.04$ \\
Reading sheets & 50 & $1-4$ & $2.30(1.09)$ & $0.34 /-1.16$ \\
Worksheets & 50 & $1-4$ & $2.30(0.72)$ & $0.46 / 0.14$ \\
Letter forming & 50 & $1-4$ & $1.92(0.81)$ & $0.57 / 0.05$ \\
Repeated letters systematically & 51 & $1-4$ & $1.73(0.98)$ & $1.12 / 0.06$ \\
Repeated letters regularly & 51 & $1-4$ & $1.61(0.85)$ & $1.12 / 0.80$ \\
Repeated letters with individual students & 51 & $1-2$ & $1.27(0.45)$ & $1.04 /-0.95$ \\
\hline
\end{tabular}

The pace of letter instruction was assessed using the item "By the end of which month did you complete the first introduction of the letters?", which was presented to all teachers in December (scale: $0=$ September to $3=$ December, or "Have not introduced all letters yet") and then given as a follow-up question in June to those teachers who first confirmed that they had not introduced all letters by December (scale: $0=$ January to $5=$ June). The teachers' answers to those two questions were combined into a continuous variable where September was coded as 0 and the following months were coded continuously up to 9 (June). Descriptive statistics for this variable are presented in Table 2.

Table 2. Distribution of classrooms across months on the "pace of letter instruction" variable.

\begin{tabular}{lc}
\hline & Number of classrooms \\
\hline September & 1 \\
October & - \\
November & 4 \\
December & 22 \\
January & 6 \\
February & 5 \\
March & 7 \\
April & 5 \\
May & - \\
June & 1 \\
Total & 51 \\
\hline
\end{tabular}

To determine whether the pace of letter instruction was associated with the frequencies of other teaching practices, a series of correlational analyses were conducted using the SPSS 25 software. For the variables based on a continuous scale ("time to read", "time to write" and "pace of letter instruction"), Pearson's correlation was used. For the remaining variables, which were based on an ordinal scale, Spearman's correlation 
was used. Survey data from both time points (December and June) were used to detect any changes in these associations between the first and the second semester.

\section{Results}

Correlational analyses of the association between the pace of letter instruction and teaching practices were first performed for the data from the December questionnaire. The results were statistically significant in only one case: less time was spent on "worksheets" when the letters were introduced faster $(r=.38, p=.01)$. By contrast, no significant correlations were found for the other five variables analysed for this time point: "time to read" $(r=.03, p=.81)$, "time to write" $(r=-.13, p=.37)$, "levelled books" $(r=-.03, p=.82)$, "reading sheets" $(r=.20, p=.15)$ or "handwriting" $(r=-.20, p=.16)$.

Then a corresponding analysis was performed based on the teachers' responses to the June questionnaire. Here it was found that introducing the letters faster was statistically significantly associated with more "time to write" $(r=-.32, p=.02)$, more use of "levelled books" ( $r=.33, p=.02)$ and less time spent on "worksheets" $(r=-.36, p=.01)$ and on "handwriting" $(r=.36, p=.01)$. By contrast, no significant correlations were detected in June either for the two other variables measured at both time points: "time to read" $(r=-.17, p=.24)$ and "reading sheets" $(r=$ $.10, p=.48)$.

As mentioned above, the teachers were asked additional questions in June relating to their practices with regard to letter repetition and adapted instruction. Here, correlational analysis yielded significant results for "repeated letters with individual students" ( $r=.30, p=.03)$, but not for the two whole-class measures of "repeated letters systematically" $(r=.16, p=.27)$ and "repeated letters regularly" $(r=.07$, $p=.61)$, nor for "adapted instruction" $(r=.08, p=.58)$.

To sum up, it would appear that the pace of letter instruction was mainly associated with teaching practices in the second semester. Hence there would seem to be an ongoing shift towards more meaningful student activities throughout the academic year.

\section{Discussion}

The aim of the present study was to investigate whether a change to an instructional cornerstone, namely the shift to a faster pace of letter instruction, would have the potential to alter other teaching practices, and also whether this effect increased from the first to the second semester. A faster pace of letter instruction has proved to be positively associated with children's literacy learning (Jones \& Reutzel, 2012; Sunde et al., 2019), but it has not previously been explored whether introducing the letters faster is also associated with teaching practices at a more general level. Our hypotheses were partially supported, as the main results showed weak associations with a 


\section{K. Sunde and K. Lundetre}

faster pace of letter instruction in the first semester and a stronger association in the second semester. Hence this study expands on previous findings by showing that the pace of letter instruction really does have the potential to alter teaching practices at a more general level.

\section{Associations between the pace of letter instruction and other teaching practices in the first semester}

The results for the first semester showed that the pace of letter instruction was statistically significantly associated only with less time being spent on worksheets, meaning that in classrooms where the letters are introduced at a faster pace, worksheets are used on a less regular basis. The reason why no other teaching practices were significantly correlated with the pace of letter instruction, may be that letter instruction was actually still ongoing in most classrooms throughout the first semester, or at least the lion's share of it (only 5 out of 51 teachers had introduced all letters by November). However, it follows from the recommendations to introduce the letters at a faster pace that only 10-15 minutes should be devoted to introducing each new letter before the letters are used for meaningful literacy activities, such as student's own reading and writing (Jones et al., 2013; Lundetræ \& Uppstad, 2016). Traditionally, as mentioned above, the introduction of a single letter was stretched out over a whole week. Our results for the first semester might indicate that the teachers who introduce more than one letter a week still rely on the old ways to some extent by taking more time than suggested to introduce a new letter. One effect of this would be that less time is freed up for meaningful reading and writing activities. At the same time, our results indicate that the pace of letter instruction is not associated with the time devoted to the practice of handwriting, meaning that teachers who introduce several letters a week do not increase the time spent on handwriting practice accordingly; this, by contrast, is in line with recent recommendations (Jones et al., 2013; Lundetræ \& Uppstad, 2016; Lundetræ \& Walgermo, 2014).

It is also possible that the modest strength of our findings for the first semester is related to the novelty of the approach. In fact, more than half of the teachers who finished letter instruction by December reported that this was the first time they had introduced the letters so quickly. Concrete classroom experiences are an important source of teacher learning and a key driver of changes in teaching practices, which are unlikely to happen unless enough time is devoted to bringing them about (Desimone, 2009; Putnam \& Borko, 2000). Hence the teachers' limited experience with this new approach might be an important factor to consider when interpreting the results for the first semester.

The recommendations to the effect that the letters should be introduced faster tend to stress the importance of providing students with ample time to read and write in parallel with letter instruction (Jones et al., 2013; Lundetræ \& Uppstad, 2016; Tønnessen \& Uppstad, 2015). In this respect, our results for the first semester are in line with those of Håland et al. (2019), which suggest that teachers who introduce the 
letters faster do not tend to increase the time available for students to read and write, although such an increase might be appropriate as a way to realise the potential for increased literacy learning that arises when the letters are introduced faster. Given that the students in classrooms where letter instruction was finished earlier gained access to a larger number of letters during the first semester, they would presumably have profited more from additional reading and writing time than the students in the slower classrooms would. An additional finding by Håland et al. (2019) was that several of the teachers who reported setting aside no time at all for students' writing in the first semester explained that introducing more letters during that semester was time-consuming and so there had not been any time left for writing. This finding is contrary to the existing recommendations, and it lends further support to the above-mentioned explanation for the lack of significant relationships in the first semester: teachers' own experiences exert an impact on the extent to which they incorporate all aspects of this, or any, new approach.

\section{Associations between the pace of letter instruction and other teaching practices in the second semester}

When it came to the second semester, the pace of letter instruction was significantly associated with more time made available for students' own writing, less time spent on worksheets and on handwriting practice, increased use of levelled books and more time devoted to repeating the letters with those students who needed more help after the first round of instruction. Taken together, these results provide support for our hypothesis that the effect of the pace of letter instruction in terms of a shift towards more meaningful literacy practices would be more clearly visible in the second semester. As the second semester progressed, more and more teachers completed letter instruction, freeing up time to be devoted to other teaching practices. However, how teachers choose to spend this time may vary a great deal.

Even though there is variation across classrooms in the amount of time provided for students' reading, the pace of letter instruction does not seem to affect how much time teachers devote to this activity. This finding is somewhat surprising, given that the opportunity for more encounters with words through reading is emphasised as an advantage of introducing the letters faster (Lundetræ \& Uppstad, 2016; Tønnessen \& Uppstad, 2015). Here it is interesting to note that the pace of letter instruction was found to be associated with more time being devoted to students' writing, and it would seem reasonable to expect the same pattern for reading. Traditionally, writing has tended to be underprivileged compared with reading at schools (Mo, Kopke, Hawkins, Troia, \& Olinghouse, 2014), and this could be one reason why teachers who find that they have more time available will devote that time to writing. The benefits of providing first-graders with time to write are numerous, which is why it is encouraging that teachers who have introduced all the letters tend to give priority to making more time available for students' writing. There are two main reasons for this: time spent writing is likely to exert a positive effect on students' reading development 
(Coker, Jennings, Farley-Ripple, Macarthur, \& Graham, 2018; Frith, 1985; Graham \& Hebert, 2011; Welsch, Sullivan, \& Justice, 2003), and writing opens up for more meaningful use of literacy skills.

Further, teachers who introduce more letters a week devote less time to worksheets and to handwriting practice. These findings are probably related to the finding that teachers who introduce the letters at a faster pace will allocate more time for students' writing. Previous research shows that tasks such as worksheet-based exercises and handwriting practice are used more in classrooms where the emphasis of literacy instruction is on teaching partial skills rather than on promoting meaningful literacy tasks (Lerkkanen et al., 2016; Stipek, 2004).

A further advantage of a faster pace of letter instruction which has been emphasised is that it offers opportunities for adapting instruction. Our results show that a faster pace of letter instruction is associated with more repetitions of the letters for those students who need them. This finding is encouraging, as children need multiple repetitions to learn the letter-sound associations (Ehri, 2004; National Institute of Child Health and Human Development, 2000). In addition, teachers who introduce more letters a week also use levelled books more often, and such books represent an opportunity to adapt reading instruction to individual students' skill level. Although our results cannot tell whether the teachers actually provided their students with books at the appropriate level, at least more extensive use of levelled books has the potential to provide students with reading material at the correct level of difficulty. Even though we found no significant correlation between the pace of letter instruction and the extent to which teachers explicitly said that they adapted literacy tasks to students' skill level, the above-mentioned findings support our hypotheses to some extent.

\section{Strengths and limitations}

The present study has several strengths. First, the sample consists of teachers allocated to the untreated control group in a large randomised controlled trial, and their response rate was very high. Second, as the pace of letter instruction is studied in a natural setting, the teachers' answers are not affected by the aim of the present study and it can be expected that the study has strong ecological validity. However, the present study also has some limitations. First, the data were collected using self-reports, which is a method with inherent uncertainty. Second - unlike, for example, classroom observations - the use of survey data does not permit any investigation of the quality of teaching. Third, the questionnaires were administered on only two occasions during the academic year. Although the teachers were asked to base their answers on a typical week during the current semester, it is reasonable to assume that teachers allocate classroom time across teaching practices unevenly in the course of a semester. If their idea of a typical week was influenced, as would not be unexpected, by what they were doing in the classroom at the time of answering the questionnaire, this may have affected the accuracy of their answers. Fourth, we did not have information on the use of STL+ (spelling 
or/and writing with audio support, using a tablet or a computer), which potentially could be associated with pace of letter instruction. Through audio support, and access to all the letters on the keyboard, the students might learn letter-sound associations prior to the formal introduction in class. There has been an increase in the use of STL+, in parallel to both the increasing number of tablets or/and computers in the lowest grades and that more teachers introduce more letters a week. Fifth, several teachers lacked previous experience with introducing the letters at a faster pace and it is not unreasonable that there may have been differences between teachers depending on their experience with this practice. However, it would obviously have been difficult to find a group of highly experienced teachers when the shift to a faster pace of letter instruction is so recent.

\section{Conclusions and implications}

The findings from the present study make a contribution to the existing pool of knowledge about pace of letter instruction by showing that this practice has the potential to alter teaching practices at a more general level, in the direction of a more "meaningful" approach to literacy instruction. It is also clear that the associations between the pace of letter instruction and other teaching practices are much more obvious in the second semester than in the first one. This finding of weak initial associations suggests that there is still room for teachers to better exploit the opportunities created by introducing the letters at a faster pace. This, in turn, points to a need to provide teachers with appropriate support during the establishment phase of a new classroom practice.

Future research should aim to broaden the methodological approach to these questions as well as investigating whether the pace of letter instruction affects additional aspects of literacy practices not included in the present study.

\section{Acknowledgements}

The "Two Teachers" project is funded by the Research Council of Norway: research programme "LÆREEFFEKT", grant number 256197.

We would like to thank Project Leader Oddny Judith Solheim for providing the data to conduct this study. We would also like to thank the research assistants, teachers and students involved in the project, and the "Two Teachers" research group for important feedback on a previous version of the manuscript.

\section{Author biography}

Kristin Sunde is $\mathrm{PhD}$ student at the Norwegian Reading Centre, University of Stavanger, and focuses on early literacy instruction. She has a master degree in special needs education, and has worked as a teachers for several years. 
Kjersti Lundetra is professor in special needs education and director of the Norwegian Reading Centre, University of Stavanger. She has been teaching early literacy instruction and reading difficulties in the teacher/master training at the University of Stavanger for several years. Her main research interests are literacy development, early literacy instruction, and literacy interventions.

\section{References}

Adams, M. J. (1990). Beginning to read:Thinking and learning about print. Cambridge, Massachusetts: The MIT Press.

Allington, R. L. (2013). What really matters when working with struggling readers. Reading Teacher, 66(7), 520-530. doi:https://doi.org/10.1002/TRTR.1154

Bartlett, M. S. (1954). A note on the multiplying factors for various chi square approximations. Fournal of the Royal Statistical Society. Series B (Methodological), 16(2), 296-298. Retrieved from http://www.jstor.org/ stable/2984057

Brenner, D., Hiebert, E. H., \& Tompkins, R. (2009). How much and what are third graders reading. In E. H. Hiebert (Ed.), Reading more, reading better (pp. 118-140). New York: The Guilford Press.

Castles, A., Rastle, K., \& Nation, K. (2018). Ending the reading wars: Reading acquisition from novice to expert. Psychological Science in the Public Interest, 19(1), 5-51. doi:https://doi.org/10.1177/1529100618772271

Coker, D. L., Jennings, A. S., Farley-Ripple, E., Macarthur, C. A., \& Graham, S. (2018). The type of writing instruction and practice matters: The direct and indirect effects of writing instruction and student practice on reading achievement. Fournal of Educational Psychology, 110(4), 502-517. doi:http://dx.doi.org/10.1037/ edu0000232

Cutler, L., \& Graham, S. (2008). Primary grade writing instruction: A national survey. Fournal of Educational Psychology, 100(4), 907. doi:http://dx.doi.org/10.1037/a0012656

Desimone, L. M. (2009). Improving impact studies of teachers' professional development: Toward better conceptualizations and measures. Educational Researcher, 38(3), 181-199. doi:https://doi.org/10.3102/ 0013189X08331140

Djuve, K. J. (2017). Hva kan elevene når de begynner på skolen? -Variasjonen i norske elevers skriftspråklige ferdigheter ved skolestart, og lerernes forutsetninger for å møte denne variasjonen [What skills do students have when starting school? -Variations in Norwegian students'literacy skills when starting school, and teacher's prerequisite for handling these variations]. (Master Thesis). University of Stavanger, Retrieved from https://brage.bibsys.no/xmlui/ bitstream/handle/11250/2453456/Djuve_Karoline.pdf?sequence=1\&isAllowed=y

Ehri, L. C. (2004). Teaching Phonemic Awareness and Phonics: An Explanation of the National Reading Panel Meta-Analyses. In P. D. McCardle \&V. Chhabra (Eds.), The voice of evidence in reading research (pp. 153-186). Baltimore: P.H. Brookes.

Ehri, L. C. (2005). Development of sight word reading: Phases and findings. In M. Snowling \& C. Hulme (Eds.), The Science of reading: a handbook (pp. 135-154). Malden, Massachusetts: Blackwell.

Foorman, B. R., Schatschneider, C., Eakin, M. N., Fletcher, J. M., Moats, L. C., \& Francis, D. J. (2006). The impact of instructional practices in Grades 1 and 2 on reading and spelling achievement in high poverty schools. Contemporary Educational Psychology, 31(1), 1-29. doi:10.1016/j.cedpsych.2004.11.003

Frith, U. (1985). Beneath the surface of developmental dyslexia. In K. Patterson, J. C. Marshall, \& M. Coltheart (Eds.), Surface dyslexia (pp. 301-330). London: Routledge.

Gadamer, H. G. (1960). Wahrheit und method, Grundzuge einer philosophischen Hermeneutik. Tübingen: Suhrkamp.

Gambrell, L. B. (2011). Seven rules of engagement: What's most important to know about motivation to read. The Reading Teacher, 65(3), 172-178. doi:https://doi.org/10.1002/TRTR.01024

Gerde, H. K., Bingham, G. E., \& Wasik, B. A. (2012). Writing in Early Childhood Classrooms: Guidance for Best Practices. Early Childhood Education fournal, 40(6), 351-359. doi:https://doi.org/10.1007/s10643-012-0531-z

Graham, S., Bollinger, A., Olson, C. B., D'Aoust, C., MacArthur, C., McCutchen, D., \& Olinghouse, N. (2012). Teaching elementary school students to be effective writers: A practice guide (NCEE 2012-4085). Washington, DC: What Works Clearinghouse Retrieved from https://files.eric.ed.gov/fulltext/ED533112.pdf

Graham, S., \& Hebert, M. (2011). Writing to read: a meta-analysis of the impact of writing and writing instruction on reading. Harvard educational review, 81(4), 710-744. doi:https://doi.org/10.17763/ haer.81.4.t $2 \mathrm{k} 0 \mathrm{~m} 13756113566$ 


\section{Is a faster pace of letter instruction associated with other teaching practices?}

Håland, A., Hoem, T. F., \& McTigue, E. M. (2019). Writing in First Grade: The Quantity and Quality of Practices in Norwegian Classrooms. Early Childhood Education fournal, 47(1), 63-74. doi:https://doi. org/10.1007/s10643-018-0908-8

Jones, C., Clark, S., \& Reutzel, R. (2013). Enhancing alphabet knowledge instruction: Research implications and practical strategies for early childhood educators. Early Childhood Education fournal, 42(2), 81-89. doi:https://doi.org/10.1007/s10643-012-0534-9

Jones, C., \& Reutzel, R. (2012). Enhanced alphabet knowledge instruction: Exploring a change of frequency, focus, and distributed cycles of review. Reading Psychology, 33(5), 448-464. doi:https://doi.org/10.1080/0 2702711.2010.545260

Justice, L. M., Pence, K., Bowles, R. B., \& Wiggins, A. (2006). An investigation of four hypotheses concerning the order by which 4-year-old children learn the alphabet letters. Early Childhood Research Quarterly, 21(3), 374-389. doi:https://doi.org/10.1016/j.ecresq.2006.07.010

Kaiser, H. F. (1970). A second generation Little Jiffy. Psychometrika, 35(4), 401-415. doi:https://doi.org/10.1007/ $\mathrm{BF} 02291817$

Kaiser, H. F. (1974). An index of factorial simplicity. Psychometrika, 39(1), 31-36. doi:https://doi.org/10.1007/ BF02291575

Lerkkanen, M.-K., Kiuru, N., Pakarinen, E., Poikkeus, A.-M., Rasku-Puttonen, H., Siekkinen, M., \& Nurmi, J.-E. (2016). Child-centered versus teacher-directed teaching practices: Associations with the development of academic skills in the first grade at school. Early Childhood Research Quarterly, 36(3), 145-156. doi:https://doi.org/10.1016/j.ecresq.2015.12.023

Lundetræ, K., \& Uppstad, P. H. (Producer). (2016). Bokstaver! [Letters!]. [Film] Retrieved from https://www. youtube.com/watch?v=S3JE7MNKMyg

Lundetræ, K., \&Walgermo, B. R. (2014). Leseopplæring - å komme på sporet [Reading instruction - getting on track]. In F. E. Tønnessen \& K. Lundetræ (Eds.), A lykkes med lesing: tidlig innsats og tilpasset leseopplcering [Being successful at reading: early interventions and differentiated reading instruction] (pp. 148-169). Oslo: Gyldendal akademisk.

Mo, Y., Kopke, R. A., Hawkins, L. K., Troia, G. A., \& Olinghouse, N. (2014). The neglected "R" in a time of Common Core. The Reading Teacher, 67(6), 445-453. doi:https://doi.org/10.1002/trtr.1227

Morrow, L. M., Tracey, D. H., \& Del Nero, J. R. (2011). Best practices in early literacy: Preschool, kindergarten and first grade. In L. M. Morrow \& L. B. Gambrell (Eds.), Best practices in literacy instruction (Fourth ed., pp. 67-95). New York: The Guilford Press.

National Institute of Child Health and Human Development. (2000). Report of the national reading panel:Teaching children to read: An evidence-based assessment of the scientific research literature on reading and its implications for reading instruction (NIH Publication No. 00-4769). Washington, DC: U.S: Government Printing Office.

Norwegian Directorate for Education and Training. (2017a). Framework plan for the content and tasks of kindergartens. Retrieved from https:/www.udir.no/globalassets/filer/barnehage/rammeplan/frameworkplan-for-kindergartens2-2017.pdf

Norwegian Directorate for Education and Training. (2017b). Knowledge promotion reform. Retrieved from https://www.udir.no/in-english/

Norwegian Directorate for Education and Training. (2018a). Fag- og timefordeling og tilbudsstruktur for Kunnskapsløftet [Course and time distribution and programme structure for the Knowledge promotion reform]. Retrieved from https://www.udir.no/regelverkstolkninger/opplaring/Innhold-i-opplaringen/udir01-2018/

Norwegian Directorate for Education and Training. (2018b). Grunnskolens informasjonssystem (GSI) 2017/18 [Information system for primary and lower-secondary school, 2017/18]. Retrieved from https:/gsi.udir. no/app/\#!/view/units/collectionset/1/collection/77/unit/1/

Norwegian Reading Centre. (2017). Førsteklassingene lærer bokstavene raskere [First-year students are learning the letters faster]. Retrieved from https://lesesenteret.uis.no/om-lesesenteret/aktuelt/forsteklassingenelarer-bokstavene-raskere-article113370-12719.html

Puranik, C. S., \& Lonigan, C. J. (2011). From scribbles to scrabble: Preschool children's developing knowledge of written language. Reading and Writing, 24(5), 567-589. doi:https://doi.org/10.1007/s11145-009-9220-8

Putnam, R. T., \& Borko, H. (2000). What do new view og knowledge and thinking have to say about research on teacher learning? Educational Researcher, 29(1), 4-15. doi:https://doi.org/10.3102/0013189X029001004

Rasmussen, A. (2013). Begynneropplcering i lesing i norske skoler - en undersøkelse av bokstavinnlcring og metodevalg [Early Literacy Instruction in Reading - A Master Thesis about letter knowledge and teaching methods]. (Master Thesis). University of Stavanger, Retrieved from https://brage.bibsys.no/xmlui/handle/11250/185828 


\section{K. Sunde and K. Lundetrce}

Ray, K.W., \& Cleaveland, L. B. (2004). About the authors:Writing workshop with our youngest writers. Portsmouth, NH: Heinemann.

Read, C. (1971). Pre-school children's knowledge of English phonology. Harvard educational review, 41(1), 1-34. doi:https://doi.org/10.17763/haer.41.1.91367v0h80051573

Roth, K., \& Guinee, K. (2011). Ten minutes a day: The impact of interactive writing instruction on first graders' independent writing. Fournal of Early Childhood Literacy, 11(3), 331-361. doi:https://doi. org/10.1177/1468798411409300

Seymour, P. H. K., Aro, M., \& Erskine, J. M. (2003). Foundation literacy acquisition in European orthographies. British Fournal of Psychology, 94(2), 143-174. doi:https://doi.org/10.1348/000712603321661859

Sigmundsson, H., Eriksen, A. D., Ofteland, G. S., \& Haga, M. (2017). Letter-sound knowledge: Exploring gender differences in children when they start school regarding knowledge of large letters, small letters, sound large letters, and sound small letters. Frontiers in Psychology, 8(1539). doi:https://doi.org/10.3389/ fpsyg.2017.01539

Solheim, O. J., Rege, M., \& McTigue, E. (2017). Study protocol: 'Two Teachers': A randomized controlled trial investigating individual and complementary effects of teacher-student ratio in literacy instruction and professional development for teachers. International fournal of Educational Research, 86, 122-130. doi:https://doi.org/10.1016/j.ijer.2017.09.002

Statistics Norway. (2017). Barnehager [Kindergartens].Retrieved fromhttps://www.ssb.no/utdanning/statistikker/ barnehager

Statistics Norway. (2018). Tettsteders befolkning og areal [Population and area of towns and villages]. Retrieved from https://www.ssb.no/befolkning/statistikker/beftett

Stipek, D. (2004). Teaching practices in kindergarten and first grade: Different strokes for different folks. Early Childhood Research Quarterly, 19(4), 548-568. doi:https://doi.org/10.1016/j.ecresq.2004.10.010

Stutz, F., Schaffner, E., \& Schiefele, U. (2016). Relations among reading motivation, reading amount, and reading comprehension in the early elementary grades. Learning and Individual differences, 45, 101-113. doi:https://doi.org/10.1016/j.lindif.2015.11.022

Sunde, K., Furnes, B., \& Lundetræ, K. (2019). Does introducing the letters at a faster pace boost the development of children's letter knowledge, word reading and spelling in the first year of school? Scientific Studies of Reading. doi:https://doi.org/10.1080/10888438.2019.1615491

Topping, K., Samuels, J., \& Paul, T. (2007). Does practice make perfect? Independent reading quantity, quality and student achievement. Learning and Instruction, 17(3), 253-264. doi:https://doi.org/10.1016/j. learninstruc.2007.02.002

Torgerson, C., Brooks, G., \& Hall, J. (2006). A systematic review of the research literature on the use of phonics in the teaching of reading and spelling. London: DfES Research Report.

Treiman, R., Tincoff, R., Rodriguez, K., Mouzaki,A., \& Francis, D. J. (1998). The foundations of literacy: Learning the sounds of letters. Child development, 69(6), 1524-1540. doi:https://doi.org/10.1111/j.1467-8624.1998. tb06175.x

Turner, J., \& Paris, S. G. (1995). How literacy tasks influence children's motivation for literacy. The Reading Teacher, 48(8), 662-673. Retrieved from https://www.jstor.org/stable/20201530?seq=1\#page_scan_tab_ contents

Tønnessen, F. E., \& Uppstad, P. H. (2015). Can we read letters? Reflections on fundamental issues in reading and dyslexia research. Rotterdam, The Nederlands: Sense Publishing.

Welsch, J. G., Sullivan, A., \& Justice, L. M. (2003). That's my letter!: What preschoolers' name writing representations tell us about emergent literacy knowledge. Fournal of Literacy Research, 35(2), 757-776. doi:https://doi.org/10.1207/s15548430jlr3502_4

Wendt, H., Bos, W., Tarelli, I., Vaskova, A., \& Walzebug, A. (2016). IGLU \& TIMSS 2011: Skalenhandbuch zur Dokumentation der Erhebungsinstrumente und Arbeit mit den Datensätzen [Scale manual on documentation of collection instruments and work on datasets]: Waxmann Verlag.

Willingham, D. T. (2017). The reading mind: a cognitive approach to understanding how the mind reads. Retrieved from https:/ebookcentral.proquest.com/lib/uisbib/detail.action?docID $=4837508$

Wray, D., Medwell, J., Fox, R., \& Poulson, L. (2000). The Teaching Practices of Effective Teachers of Literacy. Educational Review, 52(1), 75-84. doi:https://doi.org/10.1080/00131910097432 